\title{
Soil Quality Parameters and Yield of Green Gram as Affected by the Combined Application of Manures and Biofertilisers
}

\author{
Sanbharisha Dkhar ${ }^{1}$, Jurisandhya Bordoloi ${ }^{*}$, L.J. Bordooloi ${ }^{2}$ and Y.K. Sharma ${ }^{1}$ \\ ${ }^{1}$ Department of Agricultural Chemistry and Soil Science, School of Agricultural Sciences and \\ Rural Development (SASRD), Nagaland University: Medziphema Campus- 797106, \\ Nagaland, India \\ ${ }^{2}$ ICAR Research Complex for NEH Region: Nagaland Centre, Medziphema, Nagaland, India \\ *Corresponding author
}

\begin{tabular}{|l}
\hline Ke y w o r d s \\
Green gram, FYM, \\
Vermicompost, \\
PSB, Rhizobium, \\
Co-inoculation
\end{tabular}

A B S T R A C T

A field experiment was conducted at the ICAR Research farm Medziphema, Nagaland $\left(25^{\circ} 50^{\prime} 24^{\prime \prime} \mathrm{N}\right.$ latitude and $93^{\circ} 50^{\prime} 26^{\prime \prime} \mathrm{E}$ longitude) during the summer season of 2017 with green gram as test crop. Organic manures viz. Farm Yard Manure (FYM) and vermicompost were combined with biofertilizers viz. Rhizobium and phosphate solubilizing bacteria (PSB) in different combinations and were evaluated in a Randomized Block Design with three replications. The combination of vermicompost @ $5 \mathrm{t} \mathrm{ha}^{-1}+$ coinoculation with Rhizobium $+\operatorname{PSB}\left(\mathrm{T}_{7}\right)$ proved to be the best treatment in terms of maximum number of nodules $(41.33,44,18.67$ at $30,45,60$ DAS respectively), the highest grain yield $\left(13.92 \mathrm{q} \mathrm{ha}^{-1}\right)$, total biomass yield $\left(89.77 \mathrm{q} \mathrm{ha}^{-1}\right)$ and nutrient $(\mathrm{N}, \mathrm{P}, \mathrm{K})$ uptake. No significant variation was recorded in terms of soil physical parameters under study. However, available nitrogen and organic carbon content was significantly influenced in treatment $\mathrm{T}_{7}$ and $\mathrm{T}_{4}$ with vermicompost and $\mathrm{FYM}$ along with co-inoculation of Rhizobium and PSB. Population of Rhizobium and PSB $\left(58.33 \times 10^{4}\right.$ and $56 \times 10^{4} \mathrm{CFU} \mathrm{g}^{-1}$ soil respectively), soil microbial biomass carbon (1603.91 $\mu \mathrm{g} \mathrm{g}^{-1}$ soil), dehydrogenase and acid phosphatase activity was also significantly higher in $T_{7}$. However, sole inoculation of nitrogen fixers with either of the manures failed to produce similar effects. Thus combined application of manures and biofertilizers can be recommended as nutrient management strategy for yield enhancement and soil quality maintenance of green gram cultivation in acid soils of north eastern region of India.

\section{Introduction}

Green gram [Vigna radiata (L.) Wilczek] alternatively known as the mung bean is a plant species belonging to the leguminosae family which is native to the Indian subcontinent. In India, it is grown on an area of $2.75 \mathrm{~m}$ ha with average production $1.19 \mathrm{mt}$ and productivity is $432 \mathrm{~kg} \mathrm{ha}^{-1}$ (Purushottam and Singh, 2015). The north eastern region also has tremendous potential for increasing pulse production and productivity due to its favourable climatic conditions. The area and productivity of green gram in Nagaland stretches to 330 ha of the total pulse area and 510 tons of the total pulse production (Anonymous, 2013). 
Mung bean has an edge over other pulses because of its high nutritive value. It contains about $25 \%$ protein which is almost three times that of cereals. In addition to being an important source of human food and animal feed, an important feature of the mung bean crop is its ability to establish a symbiotic relationship with specific bacteria, setting up the biological nitrogen fixation in root nodules that supply the plant needs for nitrogen. The green biomass of the crop as well as residues can be incorporated in the soil for the purpose of replenishing exported plant nutrients and improving fertility status of the soil. The soil microbiological properties were also significantly higher in the soils where mung bean is incorporated in the cropping system (Kumar, 2014).

In the recent years dependence on organic sources of nutrients is increasing as these are effective in promoting health and productivity of the soil. The replenishment of nutrients and soil quality maintenance is dependent on organic materials due to beneficial impacts in terms of soil physical, chemical, and biological properties (Reddy et al., 2003). The ability of the organic materials to supply nutrients differs, as they relate to the rates of decomposition, nutrient release rates and patterns (Kumar and Goh, 1999). There are numerous reports on increased nutrient content in soil, nutrient uptake and yield in green gram due to application of organic manures like vermicompost and FYM. Organic manures enhance soil biological activity which improves nutrient mobilization from organic and chemical sources and decomposition of toxic substances (Rana et al., 2014). Biofertiliser inoculation has always positive effects on nutrient release from the manures. There lies a synergistic relationship between different plant growth promoting micro-organisms. Co-inoculation of nitrogen fixers and phosphorus solubilising microorganisms could serve dual purpose of supplying both the nutrients and may benefit plant growth than either group of organisms alone. There is a positive effect on the yield and nutrient uptake of legume crops as well as the increased nodulation due to combined inoculation of PSB and nitrogen fixers (Khan et al., 2007). Co-inoculation of nitrogen fixers and phosphate solubilizers in legumes may have synergistic effects resulting into better crop yield and $\mathrm{P}$ uptake. Being a pulse crop, green gram has low nutrient requirement. Hence, organic manures and biofertilisers can serve as an excellent substitute for chemical fertilizers. Adoptions of appropriate strategies hold a great potential in boosting the green gram yield in an effective manner.

Green gram has of late emerged as one of the best bets for enhancing farm productivity as well as soil quality in north east India. Its introduction into the cropping systems as a quick growing summer crop has immense potential in augmenting the farmer's income apart from boosting of the soil fertility, health and quality. However, a well thought out nutrient management plan has to be in place so as to help the crop perform to its full potential. The present study, therefore, have been conducted to explore potential role of organic manures and biofertilizers in order to devise a viable nutrient management plan for green gram to fit in the nutrient starved agricultural production systems of north east India, especially Nagaland.

\section{Materials and Methods}

The experimental farm was located at $25^{\circ} 50^{\prime} 24^{\prime \prime} \mathrm{N}$ latitude and of $93^{\circ} 50^{\prime} 26^{\prime \prime} \mathrm{E}$ longitude. The climate of the Medziphema area represents sub tropical with annual rainfall of 2000-2500 mm. The maximum rainfall is received during May to October while the remaining period from November to April remains comparatively dry. The average maximum and minimum temperature and 
relative humidity recorded during the period of investigation was $33.7^{\circ} \mathrm{C}$ and $11.7^{\circ} \mathrm{C}$ and $92 \%$ respectively.

The soil of the experimental plot was sandy loam in texture. The texture and initial fertility status of the soil was ascertained and determined by collecting representative soil samples randomly from different locations with soil auger at $0-15 \mathrm{~cm}$ depth. The collected samples were air dried and ground to pass through a $2 \mathrm{~mm}$ sieve and analyzed for physical, chemical and biological parameters following standard analytical procedures. $\mathrm{pH}$ of initial samples was 4.90, OC $0.51 \%$, available $\mathrm{N}, \mathrm{P}_{2} \mathrm{O}_{5}$ and $\mathrm{K}_{2} \mathrm{O}$ was $150.53,56.43$ and $268.8 \mathrm{~kg} \mathrm{ha}^{-1}$ respectively. Maximum water holding capacity of soil was $36.21 \%$ with mean weight diameter $2.11 \mathrm{~mm}$ and bulk density $\quad 1.39 \mathrm{~g} \mathrm{~cm}^{-3}$. Initial microbial population was $12.0 \times 10^{4}$ and $11.3 \times 10^{4}$ CFU $\mathrm{g}^{-1}$ soil for Rhizobium and PSB respectively. Dehydrogenase enzyme activity was recorded as $8.23 \mu \mathrm{g} \mathrm{TPF} \mathrm{g}^{-1} \mathrm{hr}^{-1}$ and acid phosphatase activity was $59.52 \mu \mathrm{g} p$ nitrophenol g $\mathrm{g}^{-1} \mathrm{hr}^{-1}$. Soil Microbial Biomass Carbon of initial soil sample was $481.41 \mu \mathrm{g}$ g ${ }^{1}$ soil.

Summer green gram variety "Pratap" was grown following recommended cultivation practices. Seven treatments consisting of $\mathrm{T}_{1}$ : Control, T2: FYM @ $1 \mathrm{tha}^{-1}, \mathrm{~T}_{3}:$ FYM @ $5 \mathrm{t}$ $\mathrm{ha}^{-1}+$ seed inoculation with Rhizobium, $\mathrm{T}_{4}$ : FYM @ $5 \mathrm{t} \mathrm{ha}^{-1}+$ seed inoculation with Rhizobium + PSB, T 5 : vermicompost @ $5 \mathrm{t}$ ha $^{-1}, \mathrm{~T}_{6}$ :vermicompost @ $5 \mathrm{t} \mathrm{ha}^{-1}+$ seed inoculation with Rhizobium, $\mathrm{T}_{7}$ : vermicompost @ $5 \mathrm{t} \mathrm{ha}^{-1}+$ seed inoculation with Rhizobium and PSB were evaluated in a Randomized Block Design with three replications. The individual plot size was 22.5 $\mathrm{m}^{2}$. Vermicompost and FYM were procured from production unit of ICAR, Nagaland Centre whereas the biofertilisers were procured from the state biofertiliser laboratory, Medziphema, Dimapur, Nagaland. Rhizobium and PSB were applied as seed treatments just before sowing @ 30 g Rhizobium/ PSB per kg seed.

Growth attributes viz. root volume and numbers of nodules were recorded at 30, 45 and 60 DAS. Grain yield and Biomass yield was also recorded. Nutrient $(\mathrm{N}, \mathrm{P}, \mathrm{K})$ uptake was calculated for both grain and stover from the yield and nutrient contents.

Soil quality parameters viz $\mathrm{pH}$, organic carbon, available $\mathrm{N}, \mathrm{P}_{2} \mathrm{O}_{5}$ and $\mathrm{K}_{2} \mathrm{O}$, mean weight diameter, bulk density, water holding capacity, microbial (Rhizobium and PSB) population, enzyme (dehydrogenase and phosphatase) activity, SMBC and basal respiration were assessed during the investigation adopting standard procedures as mentioned in the table 1. Rhizobium cell count was done in Yeast Extract Mannitol Agar while PSB cell count was done in Pikovskaya's medium.

Mean data of each quantitative trait were statistically analysed by the technique of analysis of variance. The significant difference was tested by ' $\mathrm{f}$ ' test and difference between mean by using $\mathrm{CD}$ at $5 \%$ level (Gomez and Gomez, 1984).

\section{Results and Discussion}

\section{Growth and yield of plants}

Significant variation in root volume and number of nodules at different time interval was recorded over control (Table 2). The highest root volume / maximum number of effective nodules $(2.33 \mathrm{cc} / 41.33 ; 2.67 \mathrm{cc} /$ 44.0; and $2.50 \mathrm{cc} / 18.67$ at $30 \mathrm{DAS}, 45 \mathrm{DAS}$ and 60 DAS respectively) was recorded in $\mathrm{T}_{7}$ (vermicompost@5 t ha ${ }^{-1}+$ seed inoculation with Rhizobium + PSB) followed by $\mathrm{T}_{4}$ and the lowest was observed in control $\left(\mathrm{T}_{1}\right)$. 
Choudhary et al., (2011) also reported that organic manures result in better growth and consequently exploitation of greater soil volume for nodulation. These findings are also in close conformity with Naveen et al., (2012) who reported positive influence of vermicompost and biofertilisers on growth and nodulation of the plant. Enrichment of rhizospheric $\mathrm{N}$ by vermicompost could stimulate nodule development (Shukla and Tyagi, 2009). The increased growth parameters may be attributed to increased cell division due to sufficient supply of nitrogen and phosphorus by dual inoculation of Rhizobium + PSB (Singh et al., 2013).

The maximum grain yield (13.92 $\left.\mathrm{q} \mathrm{ha}^{-1}\right)$ was recorded from the treatment $\mathrm{T}_{7}$. This is followed by the treatments $\mathrm{T}_{4}\left(12.10 \mathrm{q} \mathrm{ha}^{-1}\right)$ and $\mathrm{T}_{6}\left(12.05 \mathrm{~kg} \mathrm{ha}^{-1}\right)$. The lowest grain yield was recorded in control (7.90 q ha $\left.{ }^{-1}\right)$. Similar trend was observed in case of stover yield too (Table 2). Increased grain yield might be attributed to increased availability of nitrogen and phosphorus in soil that resulted in higher growth and development and finally the yield (Tagore et al., 2013).

\section{Soil quality parameters}

Maximum Mean weight diameter $(3.61 \mathrm{~mm})$ and water holding capacity (38.83\%) was recorded in treatment $\mathrm{T}_{7}$, however the difference was non-significant (Table 3). Negi and Gulshan (2000) also reported that manure application enhances soil organic carbon and aggregate stability and decreases bulk density.

$\mathrm{pH}$ of soils ranged between 4.97-5.23. The effect of the treatment on soil $\mathrm{pH}$ was found to be non-significant. This is in accordance with the findings of Parvathi et al., (2013) who reported that soil $\mathrm{pH}$ did not differ significantly with the application of organic manures. Soil $\mathrm{pH}$ was found non-significant because of release of organic acids that maintain the buffering capacity of the soil during the mineralization of organic manures (Srikanth et al., 2000). However, significantly higher OC $(0.59 \%)$ was recorded in treatment $\mathrm{T}_{7}$. Available fraction of soil nitrogen was found to be the highest under treatment $\mathrm{T}_{7}$ $\left(275.96 \mathrm{~kg} \mathrm{ha}^{-1}\right)$, followed by $\mathrm{T}_{4}(250.88 \mathrm{~kg}$ $\left.\mathrm{ha}^{-1}\right)$ and $\mathrm{T}_{6}\left(242.51 \mathrm{~kg} \mathrm{ha}{ }^{-1}\right)$. Available potassium though found maximum in $\mathrm{T}_{7}$, the treatment effect was non-significant (Table 3).

The application of vermicompost @ $5 \mathrm{tha}^{-1}+$ seed inoculation with Rhizobium $+\operatorname{PSB}\left(\mathrm{T}_{7}\right)$ recorded significantly highest Rhizobium population $\left(58.33 \times 10^{4} \mathrm{CFU} \mathrm{g}^{-1}\right.$ soil) and PSB population $\left(56 \times 10^{4} \mathrm{CFU} \mathrm{g}^{-1}\right.$ soil) (Table 4). The co-inoculation of the biofertilisers probably supported the growth of Rhizobium due to their role in the synthesis of extracellular polysaccharides. This is in accordance with the findings of Tagore et al., (2013) who reported the effectiveness of coinoculation of Rhizobium + PSB in increasing microbial population in soil. Application of organic manures along with Rhizobium + PSM resulted a marked increase in PSB population in soil over the other treatments (Singh et al., 2014). Further, it is known that organic manure like vermicompost stimulates soil microbial populations by supplying large amounts of readily available carbon (Das and Dkhar, 2011).

Highest microbial biomass carbon in soil (1603.91 $\mu \mathrm{g} \mathrm{g}^{-1}$ dry soil) was recorded in the soils of treatment $T_{7}$ was followed by $T_{4}$ (1157.94 $\mu \mathrm{g} \mathrm{g}^{-1}$ soil) and the lowest was recorded in control $\mathrm{T}_{1}\left(689.85 \mu \mathrm{g} \mathrm{g}^{-1}\right.$ soil). The application of vermicompost in conjunction with biofertilisers was found to be superior over the sole application of vermicompost due to the synergistic effect of the co-inoculation of biofertilisers with vermicompost. The results are in agreement with the findings of Singh et al., (2015). 
Addition of organic manures increases the microbial biomass carbon because the organic manures act as a good substrate that provides a congenial environment for the microbial growth. Supply of readily available $\mathrm{C}$ resulted in higher microbial activity and ultimately higher microbial biomass in soil (Das and Dkhar, 2012). The results are also in close conformity with the findings of Das and Dkhar (2011) who have reported that the application of organic manures enhanced the microbial biomass carbon as compared to inorganic fertilisers and control. Similar trend was observed in case of soil basal respiration, highest (6.87 $\mu \mathrm{g} \mathrm{C} \mathrm{g}^{-1} \mathrm{hr}^{-1}$ ) being under treatment $\mathrm{T}_{7}$ followed by $\mathrm{T}_{4}(6.72 \mu \mathrm{g} \mathrm{C} \mathrm{g}$ soil hr-1) However, lowest soil basal respiration (3.81 $\mu \mathrm{g} \mathrm{C} \mathrm{g}^{-1}$ soil $\mathrm{hr}^{-1}$ ) was recorded under control treatment (Table 4).
The treatment effect on soil basal respiration was not significant probably because of reduction in number of actively respiring microorganisms in soil after the harvest of the crop.

The effect of different sources of organic manures and biofertilisers was found to have significant influence on reactivity of dehydrogenase enzyme in soil. The highest dehydrogenase activity (32.23 $\mu \mathrm{g}$ TPF g ${ }^{-1}$ soil $\mathrm{h}^{-1}$ ) was recorded under $\mathrm{T} 7$ followed by $\mathrm{T}_{4}$ $\left(28.90 \mu \mathrm{g} \mathrm{TPF} \mathrm{g}^{-1}\right.$ soil $\left.^{-1}\right)$ and the lowest was recorded in $\mathrm{T}_{2}\left(7.22 \mu \mathrm{g}\right.$ TPF g ${ }^{-1}$ soil $\left.{ }^{-1}\right)$. The trend clearly demonstrated the positive influence of biofertiliser and organic manures on the abundance of microorganisms in soil (Table 4).

Table.1 Parameters analyzed

\begin{tabular}{|c|c|c|}
\hline Sl. No & Parameters & Methods followed \\
\hline \multirow[t]{4}{*}{ I } & \multicolumn{2}{|l|}{ Physical parameters } \\
\hline & a. Mean weight diameter & Wet sieving method (Yoder, 1936) \\
\hline & b. Bulk density & Core method (Black, 1965) \\
\hline & $\begin{array}{l}\text { c.Maximum water holding } \\
\text { capacity }\end{array}$ & Keen-Rackzowski box (Piper,1966) \\
\hline \multirow[t]{6}{*}{ II } & \multicolumn{2}{|l|}{ Chemical parameters } \\
\hline & a. $\mathrm{pH}$ & Glass electrode pH meter (Jackson, 1973) \\
\hline & b. Soil organic carbon & Wet oxidation method (Walkley and Black, 1934) \\
\hline & c. Available nitrogen & $\begin{array}{l}\text { Alkaline potassium permanganate method (Subbiah and Asija, } \\
\text { 1956) }\end{array}$ \\
\hline & d. Available phosphorus & Bray's method (Bray and Kurtz, 1945) \\
\hline & e. Available potassium & Neutral normal ammonium acetate method (Jackson, 1973) \\
\hline \multirow[t]{6}{*}{ III } & \multicolumn{2}{|l|}{ Biological parameters } \\
\hline & a. Microbial population & Serial dilution method (Johnson and Curl, 1972) \\
\hline & $\begin{array}{l}\text { b.Microbial biomass carbon } \\
\text { (MBC) }\end{array}$ & Fumigation extraction method (Vance et al., 1987). \\
\hline & c. Soil basal respiration (SBR) & Alkali entrapment method (Anderson, 1982) \\
\hline & d. Dehydrogenase activity & $\begin{array}{l}\text { 2-3-5-triphenyl tetrazolium chloride reduction technique (Casida, } \\
\text { 1977) }\end{array}$ \\
\hline & e. Acid phosphatase activity & p-nitrophenyl phosphate method (Tabatabai and Bremner, 1969) \\
\hline
\end{tabular}


Table. 2 Growth parameters and yield of green gram as affected by the application of manures and biofertilisers

\begin{tabular}{|c|c|c|c|c|c|c|c|c|}
\hline \multirow{3}{*}{ Treatments } & \multicolumn{3}{|c|}{ Root volume (cc) } & \multicolumn{3}{|c|}{ Nodule no. per plant } & \multirow{3}{*}{$\begin{array}{l}\text { Grain } \\
\text { yield } \\
\text { (q ha } \text { ha }^{-1}\end{array}$} & \multirow[t]{3}{*}{$\begin{array}{l}\text { Stover } \\
\text { yield }\end{array}$} \\
\hline & \multicolumn{6}{|c|}{ Days After Sowing (DAS) } & & \\
\hline & 30 & 45 & 60 & 30 & 45 & 60 & & \\
\hline$T_{1}$ : Control & 0.8 & 1.27 & 0.93 & 8.33 & 9.67 & 4.0 & 7.90 & 17.71 \\
\hline$T_{2}:$ FYM @ $5 \mathrm{tha}^{-1}$ & 1.03 & 1.37 & 1.23 & 12.33 & 11.33 & 3.67 & 8.90 & 39.04 \\
\hline $\begin{array}{l}\text { T}_{3} \text { : FYM @ } 5 \mathrm{t} \mathrm{ha}^{-1} \\
+ \text { Rhizobium, }\end{array}$ & 1.23 & 1.47 & 1.33 & 21.33 & 20.33 & 5.33 & 9.85 & 47.23 \\
\hline $\begin{array}{l}\text { T}_{4} \text { : FYM @ } 5 \mathrm{tha}^{-1} \\
\text { Rhizobium + PSB }\end{array}$ & 1.90 & 2.17 & 1.93 & 34.67 & 35.33 & 13.67 & 12.10 & 60.44 \\
\hline $\begin{array}{l}\mathrm{T}_{5}: \text { vermicompost @ } \\
5 \mathrm{t} \mathrm{ha}^{-1}\end{array}$ & 1.53 & 1.73 & 1.43 & 24.33 & 25.0 & 9.33 & 11.33 & 52.52 \\
\hline $\begin{array}{l}\text { T}_{6}: \text { vermicompost @ } \\
5 \text { t ha }^{-1}+\text { Rhizobium }\end{array}$ & 1.87 & 2.13 & 1.87 & 34.0 & 35.67 & 14.0 & 12.05 & 57.32 \\
\hline $\begin{array}{l}\mathrm{T}_{7} \text { : vermicompost @ } \\
5 \mathrm{t} \mathrm{ha}^{-1}+\text { Rhizobium } \\
+ \text { PSB }\end{array}$ & 2.33 & 2.67 & 2.5 & 41.33 & 44.0 & 18.67 & 13.92 & 75.86 \\
\hline SEm \pm & 0.06 & 0.06 & 0.06 & 1.40 & 1.12 & 0.62 & 0.20 & 0.62 \\
\hline $\mathrm{CD}(\mathbf{P}=0.05)$ & 0.22 & 0.23 & 0.23 & 5.07 & 4.06 & 2.26 & 0.72 & 2.24 \\
\hline
\end{tabular}

Table.3 Physicochemical properties of soil as affected by the application of manures and biofertilisers

\begin{tabular}{|c|c|c|c|c|c|c|c|c|}
\hline \multirow[b]{2}{*}{ Treatments } & \multirow{2}{*}{$\begin{array}{l}\text { MWD } \\
(\mathbf{m m})\end{array}$} & \multirow{2}{*}{$\begin{array}{l}\text { BD } \\
\left(\mathrm{gcm}^{-3}\right)\end{array}$} & \multirow{2}{*}{$\begin{array}{l}\text { MWHC } \\
(\%)\end{array}$} & \multirow[t]{2}{*}{ pH } & \multirow[t]{2}{*}{$\mathrm{OC}(\%)$} & \multirow{2}{*}{\multicolumn{3}{|c|}{$\begin{array}{l}\text { AvN } \\
\left(\mathrm{kgha}^{-1}\right)\end{array}$}} \\
\hline & & & & & & & & \\
\hline$T_{1}$ : Control & 2.20 & 1.31 & 35.53 & 5.17 & 0.51 & 188.16 & 20.52 & 232.96 \\
\hline $\mathrm{T}_{2}:$ FYM @ $5 \mathrm{t} \mathrm{ha}^{-1}$ & 2.39 & 1.38 & 37.70 & 5.20 & 0.55 & 200.70 & 27.36 & 277.76 \\
\hline $\begin{array}{l}\text { T }_{3} \text { : FYM @ } 5 \mathrm{t} \mathrm{ha}^{-1}+ \\
\text { Rhizobium, }\end{array}$ & 2.83 & 1.38 & 36.26 & 5.17 & 0.53 & 221.61 & 27.36 & 304.64 \\
\hline $\begin{array}{l}\text { T}_{4} \text { : FYM @ } 5 \mathrm{t} \mathrm{ha}^{-1} \\
\text { Rhizobium + PSB }\end{array}$ & 3.26 & 1.42 & 36.89 & 4.97 & 0.58 & 250.88 & 39.33 & 328.52 \\
\hline $\begin{array}{l}\mathrm{T}_{5}: \text { vermicompost @ } \\
5 \mathrm{t} \mathrm{ha}^{-1}\end{array}$ & 3.10 & 1.37 & 35.80 & 5.20 & 0.54 & 213.24 & 30.78 & 328.52 \\
\hline $\begin{array}{l}\mathrm{T}_{6} \text { :vermicompost @ } \\
5 \mathrm{t} \mathrm{ha}^{-1}+\text { Rhizobium }\end{array}$ & 3.32 & 1.39 & 38.29 & 5.23 & 0.56 & 242.51 & 25.65 & 313.60 \\
\hline $\begin{array}{l}\text { T}_{7} \text { : vermicompost @ } \\
5 \mathrm{t} \mathrm{ha}^{-1}+\text { Rhizobium } \\
+ \text { PSB }\end{array}$ & 3.61 & 1.36 & 38.83 & 5.13 & 0.59 & 275.96 & 32.49 & 349.44 \\
\hline SEm \pm & 0.03 & 0.02 & 1.46 & 0.14 & 0.01 & 14.08 & 6.56 & 29.78 \\
\hline $\mathrm{CD}(\mathrm{P}=0.05)$ & 0.12 & NS & NS & NS & 0.05 & 50.97 & 23.77 & 107.82 \\
\hline Initial value & 2.11 & 1.39 & 36.21 & 4.90 & 0.51 & 150.33 & 15.51 & 268.80 \\
\hline
\end{tabular}


Table.4 Soil biological properties as affected by manures and biofertilizers

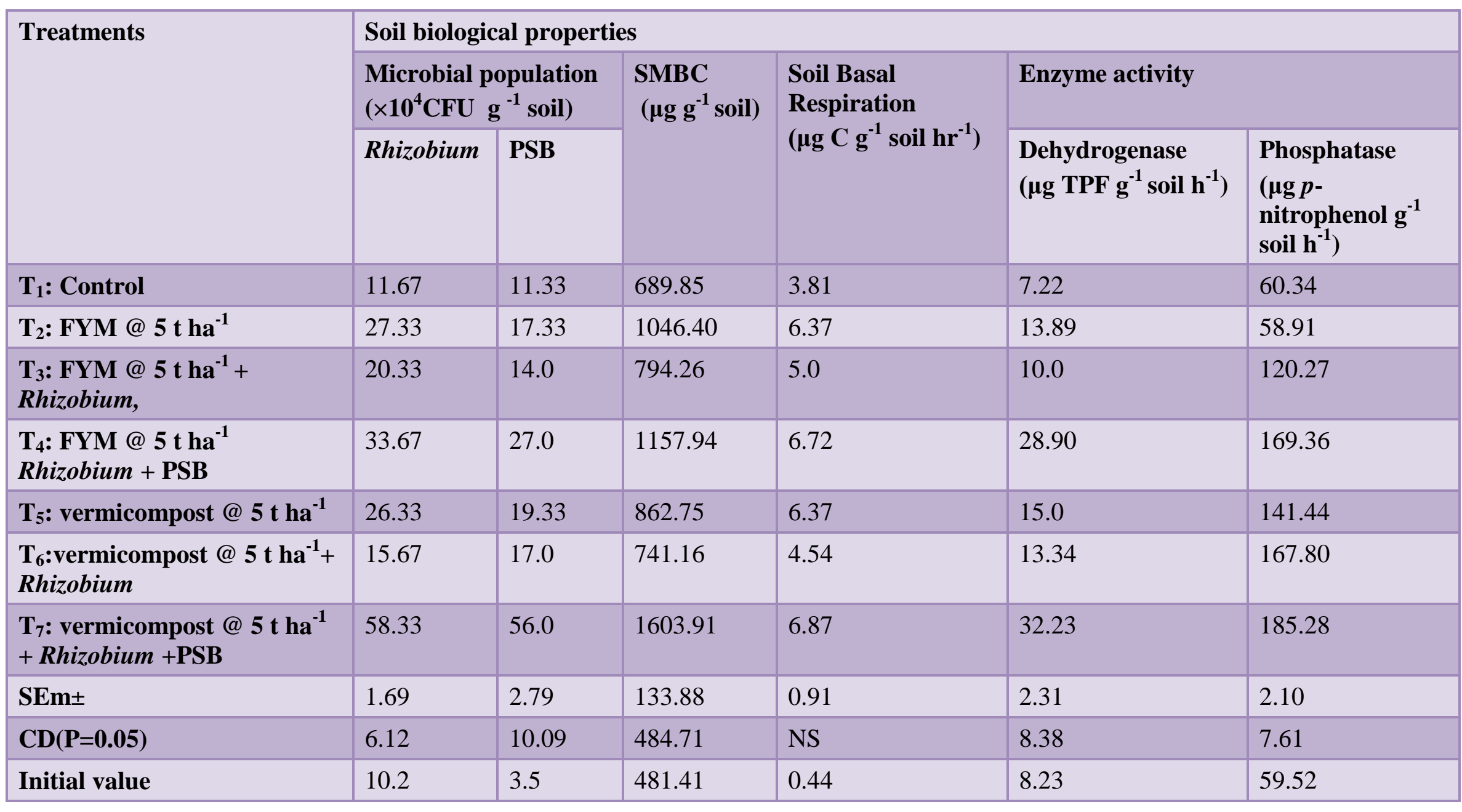


The application of vermicompost enhances dehydrogenase activity which reflects the total range of oxidative activity of soil microflora and is consequently used as an indicator of soil microbial activity. Marinari et al., (2000) reported that the enzymatic activities in soil were higher in organically amended soils than in control and soils treated with mineral fertilizer. Acid phosphatase activity was also found to be the highest under $\mathrm{T}_{7}\left(185.28 \mu \mathrm{g}\right.$ p-nitrophenol $\mathrm{g}^{-1}$ soil $\left.^{-1}\right)$ followed by $\mathrm{T}_{4}\left(169.36 \mu \mathrm{g} p\right.$-nitrophenol $\mathrm{g}^{-1}$ soil $\mathrm{h}^{-1}$ ) and the lowest was recorded in $\mathrm{T}_{2}$ (58.91 $\mu \mathrm{g} p$-nitrophenol $\mathrm{g}^{-1}$ soil $^{-1}$ ) (Table 4). The plots receiving only vermicompost showed a significantly lower phosphatase activity as compared to that received vermicompost in conjunction with PSB. The phosphatase activity was stimulated by the application of biofertilisers. These findings are in agreement with Singh et al., (2015).

From the above discussion it can be concluded that introduction of green gram into the cropping systems as a quick growing summer crop has immense potential in augmenting the farmer's income apart from boosting of the soil fertility, health and quality. Green gram can be grown successfully with judicious use of organic manures and biofertilisers. Combined inoculation of nitrogen fixers and phosphate solubilisers can bring about even better improvement in productive performance of green gram than either group of organisms alone due to synergistic effect, which was obvious in the present investigation. The application of vermicompost @ $5 \mathrm{tha}^{-1}+$ seed inoculation with Rhizobium + PSB was found to be the best treatment which resulted $76.2 \%$ increase in yield over control, besides contributing substantially to other growth attributes as well as improving physical, chemical and biological properties of soil. Hence, application of vermicompost along with co-inoculation of seed with Rhizobium and PSB can be a nutrient management strategy for improving the productivity of green gram in phosphorus deficient acid soils of north eastern region.

\section{References}

Anderson, J.P.E. 1982. Soil respiration. In: Methods of Soil Analysis. Part 2. $2^{\text {nd }}$ ed. (A.L. Page, R.H. Miller, D.R. Keeney, Eds.), pp 837-871. Madison, Wisc: ASA, SSSA.

Anonymous. 2013. Statistical Handbook of Nagaland. Directorate of Economic Statistics Government of Nagaland, Kohima.

Black, C.A. 1965. Methods of Soil Analysis. Vol I. American Society of Agronomy, Madison, Wisconsin, USA.

Bray, R. H. and Kurtz, L. T. 1945. Determination of total, organic, and available forms of phosphorus in soils. Soil Science. 59: 39-45.

Casida, L.E. 1977. Microbial metabolic activity in soil as measured by dehydrogenase determinations. Applied and Environmental Microbiology. 34(6): 630-636.

Choudhary, H. R., Sharma, O. P., Yadav, L.R and Choudhary, G. L. 2011. Effect of organic sources and chemical fertilizers on productivity of mungbean. Journal of Food Legumes. 24 (4): 324-326.

Das, Bibhuti B. and Dkhar, M. S. 2011. Rhizosphere microbial populations and physico chemical properties as affected by organic and inorganic farming practices. American-Eurasian Journal of Agricultural and Environmental Science. 10 (2): 140150.

Das, Bibhuti B. and Dkhar, M. S. 2012. Organic amendments effects on microbial population and microbial 
biomass carbon in the rhizosphere soil of soybean. Communications in Soil Science and plant analysis. 43 (14): 1938-1948.

Gomez, K.A. and Gomez, A.A. 1984. Statistical Procedure for Agricultural Reasearch. A Wiley-Interscience Publication. John Wiley and Sons, New York. pp 20-30.

Jackson, M. L. 1973. Soil Chemical Analysis. Prentice Hall of India (Pvt.) Ltd., New Delhi.

Johnson, L.F. and Curl, E.A. 1972. Methods for the research on ecology of soilborne plant pathogens, Burgess Publishing Company, Minneapolis.

Khan, M. S., Zaidi, A. and Wani, P. A. 2007. Role of phosphate solubilising microorganisms on sustainable agriculture - a review. Agronomy for sustainable development. 27: 29-43.

Kumar, K. and Goh, K. M. (1999) Crop residues and management practices: Effect on soil quality, soil nitrogen dynamics, crop yields and nitrogen recovery. Advances in Agronomy. 68: 197-319.

Kumar, D. 2014. Influence of nutrient sources and inclusion of mung bean on productivity, soil fertility and profitability of organic rice-wheat cropping system. In: Building Organic Bridges (G. Rahman and U. Aksoy, Eds.), pp 655-658. Proceedings of the $4^{\text {th }}$ ISOFAR Scientific Conference, Organic world congress 2014, Istanbul, Turkey.

Naveen, K. H. and Mevada, K. D. 2012. Performance of different composts and biofertiliser on yield and quality of green gram (Vigna radiata L.). Advance Research Journal of Crop Improvement . 3 (1): 17-20.

Marinari, S., Masciandaro, G., Ceccanti, B. and Grego, S. 2000. Influence of organic and mineral fertilizer on soil biological and physical properties. Bioresource Technology.72: 9-17.

Negi, S. C. and Gulshan, M. 2000. Effect of FYM, planting methods and fertilizer levels on rainfed wheat. Crop Research Hisar. 3 (20):534-536.

Parvathi, E., Venkaiah, K., Munaswamy, V., Naidu, M.V.S., Giridhara Krishna, T. and Prasad, T.N.V.K.V. 2013. Longterm effect of manure and fertilisers on the soil physical and chemical properties of an alfisol under semi-arid rainfed conditions. International Journal of Agricultural Science. 3 (4): 500-505.

Piper, C.S. (1966) Soils and Plant Analysis. Hans Publisher, Mumbai.

Purushottam and Singh, D. 2015. Pulses production and productivity in India. In: Pulses handbook 2015, pp 38-40. Foretell Business Solutions Pvt. Ltd., Bangalore.

Rana, R., Badiyala, D., Ramesh and Kaushal, S. 2014. Effect of organic manures on sustainable agriculture and soil quality. Popular Kheti . 2 (2): 65-70.

Reddy, B.V.S., Reddy, P.S., Bidinger, F. and Blummel. M. 2003. Crop management factors influencing yield and quality of crop residues. Field Crops Research. 84: 57-77.

Shukla, L. and Tyagi, S. P. 2009. Effect of integrated application of organic manures on soil parameters and growth of mungbean (Vigna radiata). Indian Journal of Agricultural Sciences. 79 (3): 174-177.

Singh, A., Srivastava, V. K., Meena, R. S., Kumar, S. and Kumar, Shushil. 2013. Effect of biofertilisers and N P levels on growth parameters of green gram under custard apple based agri-horti system. Agriculture for Sustainable Development. 1 (1): 61-63.

Singh, Shailesh Kumar, Singh, V. K. and Singh, S.K. 2014. Effect of 
biofertilisers and organic manures on soil microbial population at different growth stages of mungbean in an inceptisol. New Agriculturist. 25 (2): 219-222.

Singh, G., Kumar, D. and Sharma, P. 2015. Effect of organics, biofertilizers and crop residue application on soil microbial activity in rice - wheat and rice-wheat mungbean cropping systems in the Indo-Gangetic plains. Cogent Geoscience. 1 (1): 1-14.

Srikanth, K., Srinivasamurthy, C. A., Siddaramappa, R. and Ramakrishnaparama, V. R. 2000. Direct and residual effect of enriched composts, FYM, vermicompost and fertilisers on properties of an alfisol. Journal of Indian Society of Soil Science. 48 (3): 496-499.

Subbiah, B. V. and Asija, G.L. 1956. A rapid procedure for the estimation of available nitrogen in soils. Current Science. 25: 259-260.

Tabatabai, M. A. and Bremner, J. M. 1969. Use of $p$-nitrophenol phosphate for assay of soil phosphatase activity. Soil Biology and Biochemistry. 1 (4): 301-
307.

Tagore, G. S., Namdeo, S. L., Sharma, S. K. and Kumar, N. 2013. Effect of Rhizobium and phosphate solubilizing bacterial inoculants on symbiotic traits, nodule leghaemoglobin, and yield of chickpea genotypes. International Journal of Agronomy. 58 (2): 1-8.

Vance, E.D., Brookes, P.C. and Jenkinson, D.S. 1987. An extraction method for measuring soil microbial biomass $\mathrm{C}$. Soil Biology and Biochemistry. 19: 703-707.

Walkley, A. and Black, I.A.1934. An examination of the different method for determining organic carbon in soils: effect of variations in digestion conditions and of inorganic soil constituents. Soil Science. 63: 251263.

Yoder, R. F. 1936. A direct method of aggregate analysis of soils and a study of physical nature of erosion losses. Journal of American Society of Agronomy. 28: 337-351.

\section{How to cite this article:}

Sanbharisha Dkhar, Jurisandhya Bordoloi, L.J. Bordooloi and Sharma, Y.K. 2019. Soil Quality Parameters and Yield of Green Gram as Affected by the Combined Application of Manures and Biofertilisers. Int.J.Curr.Microbiol.App.Sci. 8(04): 23-32. doi: https://doi.org/10.20546/ijcmas.2019.804.003 